\title{
Pitungan and birth variations of first-born among Javanese ethnic population in Indonesia
}

\section{Pitungan dan variasi kelahiran anak pertama pada etnis Jawa di Indonesia}

\author{
Lucy Dyah Hendrawati \\ Department of Anthropology, Faculty of Social and Political Sciences, Universitas Airlangga \\ Address: Jalan Dharmawangsa Dalam, Airlangga, Surabaya, East Java, Indonesia 60286 \\ E-mail: lucydyah.h@gmail.com
}

Article History: Received 03 May 2021; Accepted 18 October 2021; Published Online 01 December 2021

\begin{abstract}
There is a phenomenon among the Javanese ethnic population, in which many wedding ceremonies are held whenever the Javanese calendar points to particular months such as Besar, Rejeb, and Ruwah, because marrying in those months is believed to bring good fortune. This study aimed to analyze the influence of wedding date determination through pitungan and feeling safe on birth variations of first-born and the number of children the wife gives birth to. The research was conducted in Blitar City, Blitar Regency, and Surabaya City with 193 married couples. Linear Regression and Chi-square were the statistical tests used in this research. Chi-square and Linear Regression tests proved that pitungan affects the birth variations of first-born $(p=0.004 ; p=0.004)$ and the number of children a couple has $(p=0.007 ; p=0.002)$. Both Chi-square and Linear Regression proved that feeling safe (roso slamet) does not have any significant effect on birth variations of first-born $(p=0.162 ; p=0.767)$ and the number of children in household $(p=0.863 ; p=0.680)$. The conclusion is that there is an important relationship between pitungan and birth variation in which the more pitungan is done, the sooner first-born is given birth to and the more children a married couple has.
\end{abstract}

Keywords: birth variations of first-born; feeling safe; pitungan; primbon

\begin{abstract}
Abstrak
Ada fenomena di masyarakat, terutama etnis Jawa, di mana perkawinan sering kali diselenggarakan setiap memasuki bulan-bulan Jawa seperti bulan Besar, Rejeb, dan Ruwah, karena dianggap sebagai bulan "baik". Tujuan penelitian ini adalah untuk menganalisis adanya pengaruh perhitungan perjodohan dan perasaan aman terhadap variasi kelahiran anak pertama dan jumlah anak yang dilahirkan pada etnis Jawa. Penelitian ini dilakukan di Kota Blitar, Kabupaten Blitar, dan Kota Surabaya dengan jumlah 193 pasangan suami istri. Uji statistik yang digunakan adalah Regresi Linear dan Chi-square. Berdasarkan uji statistik Chi-square dan Regresi Linear, terbukti bahwa ada pengaruh variabel pitungan terhadap variabel variasi musim kelahiran anak pertama $(p=0,004 ; p=0,004))$ dan jumlah anak yang dilahirkan $(p=0,007 ; p=0,002)$. Uji statistik Chi-square dan uji Regresi Linear menjelaskan bahwa tidak ada pengaruh yang signifikan antara variabel perasaan aman (roso slamet) terhadap variasi kelahiran anak pertama $(p=0,162 ; p=0,767)$ dan jumlah anak yang dilahirkan ( $p$ $=0,862 ; p=0,680)$. Simpulan penelitian menunjukkan adanya pengaruh pitungan dan variasi kelahiran anak pertama, di mana semakin tinggi pitungan dilakukan untuk menentukan waktu perkawinan, maka semakin cepat variasi kelahiran anak pertama dan jumlah anak yang dilahirkan lebih banyak.
\end{abstract}

Kata kunci: variasi kelahiran anak pertama; perasaan aman; pitungan; primbon

\section{Introduction}

In Indonesia, based on the National Socio-economic Survey Indonesia data, the maternal mortality rate in 2015 was fairly high at 305 per 100,000 populations and the infant mortality rate in 2017 was 24 per 1,000 live births (Purnamasari 2021). These data made this research essential to be conducted. Accordingly, the government, especially hospitals, health centers, medical personnel, and married couples can be well-prepared. Besides, adequate health facilities could be more prepared in the peak season of births in certain months that consequently lead to the reduction of the maternal mortality rate 
and childbirth in Indonesia. Along with this, pre-marriage counseling guidance will place more concerns on the importance of being physically healthy.

Javanese people enter the month of Jumadilakir, Besar, and Ruwah when a lot of celebrations or parties are held, especially weddings. These months are believed to be "good" months for having a marriage. The months are considered "good" because those months are "mating season" for the Javanese. According to Emlen (1984), the causes of environmental changes in population dynamics are: 1) the environment is never constant, it always changes, 2) food supplies always vary, as a result of environmental changes, and 3) the climate changes as a result of environmental changes, in which there are different individual migrations and emigrations.

Changes in reproductive ability in populations are often influenced by the internal and external environment, particularly nutrition, disease, temperature, altitude of residence, occupation, and culture (Rosetta 2007). Research was conducted by Bailey (2008) in Ituri Forest, Zaire, which is inhabited by the Lese villagers and Efe (Pygmies). Lese farmers live in the Ituri Forest, Zaire, as subsistence farmers and the Efe (Pygmies) are breeders. Bailey proves that in the population of subsistence farmers (Lese), there is a significant correlation between the birth season and a decrease in the rate of conception when food stock is limited. Limited food makes the nutritional status of the Lese woman population low so that ovarian function decreases, which is reduced as measured by steroid levels in saliva. Meanwhile, the Efe (Pygmies) is breeders who also live in the same geographic area, but they are less dependent on plant cultivation and their way of life is more flexible, therefore the research results prove that there is no significant connection between the season of birth and the frequency of conception.

Previous studies have found that seasonal variation in birth is related to climate variables, through the rainfall chain which results in food production. Food production is maintaining the balance of energy that influences ovarian function. Therefore, there are variations in human birth. This ecological approach has very complex applications as it is involved food production, energy balance, economy, and culture (Bailey 2008). Fialova in Bobak (2001) pointed out that cultural factors play a role in birth seasonality. For example, the birth month affects the number of conceptions of women, resulting in changes in the birth rate. Usually, this occurs in populations that are still traditional (Bobak 2001). In modern populations, the occurrence of conception generally depends on the choice of time to get pregnant (due to contraceptive use) rather than on climate or length of the marriage.

Henneberg (1977) conducted research in Poland based on birth records from the 19th century. $\mathrm{He}$ concluded that birth rhythms are a phenomenon caused by a culture that has no relationship with human biological traits or a direct relationship to climatic conditions. Factors that affect the birth rhythm are technological and organizational factors, including factors related to the agricultural working season, community habits, and customs. Besides being influenced by the physical environment, biological processes and genetic factors also affect human behavior. According to the theory of Evolutionary Psychology introduced by David M. Buss, the choice of behavior, emotional reaction, and attitude to some extent are influenced by the human biological trait (Baron 2004).

Differences in conceptions are also caused by differences in socio-cultural factors. This difference is often caused by differences in the events of religious celebrations or in some aspects of the religious calendar (Rajan 2000). This determines the occurrence of differences in conception patterns, especially in developing societies, which consequently results in different variations in births. The substance of other socio-cultural factors is the cycle of activity seasons and their interactions will forcibly shape the annual activity. For example, in the agricultural population, they will do a cluster of mating before or after the main season of agricultural activities (Danubio 2001).

The results of the research explained above show that, in general, culture and religious celebrations tend to be used as coordination between the calendar of activities and subsistence activities (for agricultural communities). This is the reason that subsistence (agriculture) societies form a culture of conception 
patterns as a result of ecological boundaries. The formation of a conception pattern will produce a definite birth season in the subsistence population based on each region (Condon 1982).

The results of research conducted by Johnson et al. (1975) proved that social influences and cultural events had an impact on the number of births in Peninsular Malaysia (1964-1969). The number of births increases in January due to the "Marriage Boom" occurring after the month of Ramadan (the month of fasting) because, during Ramadan, people in Peninsular Malaysia believe that there are religious sanctions for marrying. Meanwhile, the peak of births for people living in non-Muslim areas such as ethnic Chinese occurs after they conduct the Chinese New Year. According to Johnson et al. (1975), climate factors are related to work patterns or eating abilities which have an indirect effect on cultural patterns of regulation, for example, marriage arrangements. However, the birth pattern in Peninsular Malaysia from 1976 to 1985 underwent changes due to the rapid development of the economy which had an impact on demographic changes. As the use of contraceptives increases and the birth rate decreases, the birth season patterns in Malaysia also disappear (Holland 1989).

Javanese society is an agrarian society that relies on agricultural activities. The agricultural cycle in Java, especially rice fields, starts at the end of the dry season which is in October or November based on the calendar. However, the cycle begins based on the primbon book calculation system which is carried out by farmers with the help of dukun (shaman) petangan, so it is said that belief in primbon emerged from the adaptation process of the agricultural environment to cultural behavior patterns (Koentjaraningrat 1994).

Subalidinata (1985) in Poerwadarminta states that the word primbon is defined as layang kang ngemot pitungan, pethek, lan sapanunggalane (a letter containing calculations, assumptions, and the like). It is a book containing forecasting and so on. The word primbon comes from pari-imbu-an, in which the word imbu means to save or store. Iwo in Old Javanese language means to store, so parimbon can be defined as "a place to store". It is a book in which all important notes are kept and are not easily memorized by people. In fact, primbon is a book where everything related to the life of the Javanese is stored (Soedarsono et al. 1985). Primbon contains at least (1) pranatamangsa/weather forecast, (2) pitungan/ calculation, (3) panagan/wealth, (4) pawukon/harvesting calculation, (5) katuranggan, (6) treatment, (7) wirid/religious advice, (8) aji-aji/jimat or amulet, (9) kidung/chant, (10) premonition, (11) slametan/ thanksgiving procedures, (12) sasmita/supernatural addressing (Endraswara 2012).

The Javanese have a sharp perception of time. They even have a complicated way of determining it. The ability to feel the rhythm of time is determined in a traditional way, one of which is by calculating important moments such as the agricultural cycle, determining the day and month of marriage, relocation, and so on. Calculations are used to determine dates that are religion-magi to start an important job (Koentjaraningrat 1994).

Meijer (1971) argues that the wedding date determination is carried out by calculation which often results in the long delay of the wedding. The months of marriage that are considered "good" for celebrating a wedding (ijab) are in the months of Jumadilakhir, Rejeb, Ruwah and Besar. Months that are considered "good enough" for marriage (ijab) are Sapar, Bakdomulud, Jumadilawal, and Sawal. Meanwhile, the months that are considered "abstinence or forbidden" to do marriage is Suro, Mulud, Pasa, and Sela. If it is violated, the bride, groom, and their family will have a big disaster in their life (Koentjaraningrat 1994).

Javanese society is a society with an agrarian culture so that one key element in understanding life in Java is their desire for order. This order is perceived to be supernatural and beyond one's direct control. Based on early observations in Blitar and Surabaya, most people still claim to be Javanese, even though their lives have been greatly influenced by modern lifestyles. They believe in primbon to determine the time whether the wedding is carried out or not and they adhere to it. This is because, basically, the Javanese want their life to be "slamet" or have a safe life so that they will not carry out activities outside 
the beliefs that have been agreed upon by their cultural community. Javanese society believes that they have found a reaction in which self-declaration takes place side by side with their lives (Mulder 2006).

The magical and important rule in this matchmaking process is involving the birthdays (weton) of the prospective bride and groom that lead the family to negotiate and do calculations with a person who is elder and understands various things that is responsible to do the calculation. The person in charge must be able to do the calculation (pitungan) whether or not there is a match between the future bride's and groom's birthdays as an indication of the character of each pair of the couple. The compatibility of this calculation is considered important because it becomes the basis of their family's happiness and longevity. The strong belief in primbon to calculate the time of wedding among Javanese has initiated this research which focuses on the influence of pitungan or primbon calculation on the birth variations of first-born in Javanese and the influence of roso slamet or feeling save on the birth variations of first-born and the number of children born in Javanese ethnicity in Indonesia.

\section{Research Method}

The research was conducted in Surabaya, Blitar, and some districts of Blitar Regency. This is because the area preserves Mataraman culture as the people in their socio-cultural life still obey the values, norms, and rules like the Mataram people in the past, such as performing ruwatan ritual or traditional ceremonies, cleaning villages, and deciding or celebrating marriages using pitungan based on the Javanese calendar (Sutarto 2006).

The research locations of the research subject who lives in Blitar Regency were in the following areas: Kademangan District (Dawuhan, Plosorejo, and Sumberejo Village); Blitar City was particularly in Sananwetan District (Sananwetan and Bendogerit); and Surabaya was in the following areas: Kenjeran District (Tanah Kali Kedinding Sub-district) and Tambaksari District (Gading and Kapas Madya Village). The reason for choosing the area in Kademangan District, Blitar Regency, was because most of the population is Javanese, most of them work as farmers, their level of education was considered low, and many still believe in and understand pitungan. Sanawetan District of Blitar was chosen for its Javanese population, many residents work as employees, and most of their education level is Senior High School and Undergraduate. Surabaya was chosen as the research location because it is the second metropolitan city after Jakarta. Surabaya is the city of industry, maritime, and trade that is inhabited by various ethnicities and religions. Data from DPMPTSP of Surabaya City (2017) proves that $83.68 \%$ of the area are inhabited by Javanese people.

The sample selection technique was the purposive sampling technique. The samples in this study were couples over 18 years old, couples who were newlywed and had children and did not use contraception at the time of their first marriage, and married couples living at home. The total sample (n) taken from the three populations was obtained from the selected sub-districts in the study based on the population, which was calculated as follows (Mantra 2007):

$$
S=\frac{X^{2} N P(1-P)}{d^{2}(N-1)+X^{2} P(1-P)}
$$

Of the 793 couples in Blitar City and Blitar Regency and 654 couples in Surabaya City, the number of couples who met the inclusion criteria was 169 couples in Blitar City and Blitar Regency and 127 couples in Surabaya City. Based on the calculation above, the sample showed 73,76 $\approx 74$ pairs in Blitar City, Blitar Regency, and Surabaya City. The number of research subjects per district is shown in Table 1. 
Table 1.

The number of research subjects per district

\begin{tabular}{lccclc}
\hline \multicolumn{1}{c}{ Blitar City } & $\begin{array}{c}\text { Married } \\
\text { couples }\end{array}$ & $\begin{array}{c}\text { Blitar } \\
\text { Regency }\end{array}$ & $\begin{array}{c}\text { Married } \\
\text { couples }\end{array}$ & Surabaya City & $\begin{array}{c}\text { Married } \\
\text { couples }\end{array}$ \\
\hline Bendogerit & 24 & Sumberejo & 23 & Gading & 25 \\
Sananwetan & 25 & Plosorejo & 25 & Kapas Madya & 25 \\
& & Dawuhan & 24 & Tanah Kali & 23 \\
\hline Total & 49 & & 72 & & 73 \\
\hline \multicolumn{5}{r}{} \\
& & Source: Primary data &
\end{tabular}

The independent variable examined in this study was the variable of calculation of marriage. The variable affected in this study was the variable of birth variations of first-born to the married couples who carried out the time of marriage based on the calculation. The intervening variable was the variable of roso slamet or feeling safe. The confounding variable was the variable of belief in primbon.

Validity is the accuracy of a tool used as a measuring tool for a particular object. This measurement is carried out using the Chi-square correlation technique. This technique aims to test nominal data that is categorical. The benefit of the Chi-square distribution is testing the proportions for multinomial data (Siegel 1997). The calculation of the Chi-square statistical test is useful to see whether or not there is variation in the analyzed variables. These results will present whether the variables are the same or varied, therefore the diversity can be shown. Linear Regression is one of the statistical methods that function to test the extent of the causal relationship between the Causing Factor Variable (X) and the Effect Variable. Simple Linear Regression or commonly known as SLR is also used in production to make predictions about quality and quantity characteristics.

\section{Results and Discussion}

\section{Research data using the Chi-square test and Linear Regression test}

The following are the results of the processed data using the Chi-square and the Linear Regression statistical test.

Table 2.

Analysis results of Chi-square and Linear Regression about the variable of believe/disbelieve in primbon on the variable of carrying our/not carrying out pitungan

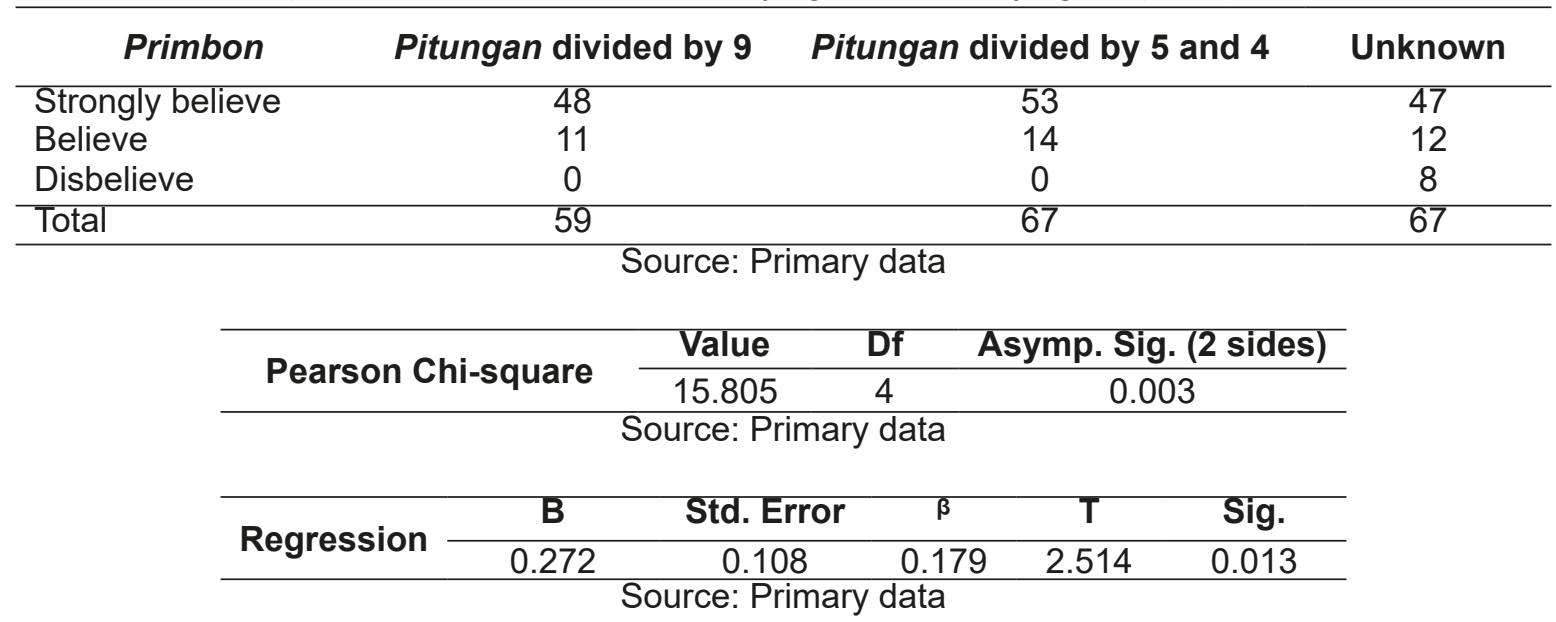

Based on Table 2, the results of the Chi-square test analysis show that the variable of belief in primbon on the variable of pitungan shows a probability value $=0.003$. This result is less than the alpha of $5 \%$, meaning that there is an effect of the variable of belief in primbon on the variable of pitungan. 
The results of the Linear Regression analysis show that $\mathrm{Y}=1.695+0.272 \mathrm{X}$, where the effect of the variable of belief in primbon on the variable of pitungan is 0.272 (positive) and the probability value $=$ 0.013 is smaller than the alpha of $5 \%$. Thus, it is significant that the more married couples believe in the primbon, then the couples more likely to carry out pitungan (Table 2).

Table 3.

Analysis results of Chi-square and Linear Regression about the variable of believe/disbelieve in primbon to the variable of birth variations of first-born

\begin{tabular}{lccc}
\hline \multicolumn{1}{c}{ Primbon } & Fast (<13 months) & Average (13-23 months) & Long (>24 months) \\
\hline Strongly believe & 86 & 45 & 17 \\
Believe & 19 & 13 & 5 \\
Disbelieve & 2 & 2 & 4 \\
\hline Total & 107 & 60 & 25
\end{tabular}

\begin{tabular}{cccccc}
\hline \multirow{2}{*}{ Pearson Chi-square } & Value & df & \multicolumn{2}{c}{ Asymp. Sig. (2 sides) } \\
\cline { 2 - 6 } & 10.308 & 4 & 0.036 \\
\hline & Source: Primary data \\
\multirow{2}{*}{ Regression } & B & Std. Error & $\beta$ & T & Sig. \\
\cline { 2 - 6 } & 0.225 & 0.096 & 0.167 & 2.337 & 0.020 \\
\hline \multicolumn{5}{c}{ Source: Primary data }
\end{tabular}

As shown in Table 3, the results of the Chi-square test analysis showed that the variable of belief in primbon towards the birth variations of first-born has a probability value of $=0.036$. This result is less than the alpha of $5 \%$, which means that there is an effect of the variable of belief in primbon on the variable of birth variations of first-born.

The results of the Linear Regression analysis show that $Y=1.294+0.225 X$, where the effect of the variable of belief in primbon on the variable of birth variations of first-born is 0.225 (positive), and the probability value $=0.020$ is smaller than the alpha of $5 \%$. Thus, it is significant that married couples are increasingly believing in primbon as they are getting their first-born faster (Table 3).

Table 4.

Analysis results of Chi-square and Linear Regression the variable of believe/disbelieve in primbon on the variable of the number of children of married couple

\begin{tabular}{lcc}
\hline \multicolumn{1}{c}{ Primbon } & At least 2 & More than 2 \\
\hline Strongly believe & 72 & 76 \\
Believe & 21 & 16 \\
Disbelieve & 7 & 1 \\
\hline Total & 100 & 93 \\
\hline
\end{tabular}

\begin{tabular}{cccc}
\hline \multirow{2}{*}{ Pearson Chi-square } & Value & Df & Asymp. Sig. (2 sides) \\
\cline { 2 - 4 } & 5.037 & 2 & 0.081 \\
\hline \multirow{4}{*}{ Source: Primary data } &
\end{tabular}

\begin{tabular}{cccccc}
\hline \multirow{2}{*}{ Regression } & B & Std. Error & $\beta$ & T & Sig. \\
\cline { 2 - 5 } & -0.138 & 0.067 & -0.147 & -2.057 & 0.041 \\
\hline \multicolumn{5}{c}{ Source: Primary data }
\end{tabular}

In Table 4, the results of the Chi-square test analysis of the relationship between the variable of belief in primbon on the variable of the number of children of married couple has a probability value $=0.081$. This result is smaller than the alpha of $10 \%$, which indicates that there is an effect between both variables. 
The results of the linear regression analysis show that $\mathrm{Y}=1.658-0.138 \mathrm{X}$, where the effect of the variable of belief in primbon on the variable of the number of children is -0.138 (negative) and the probability value $=0.041$ is smaller than the alpha of $10 \%$ which is significant, with a negative regression coefficient explains the more the married couples believe in primbon, the more the number of children will be born (Table 4).

Table 5.

Analysis results of Chi-square and Linear Regression about the variable of carrying out/not carrying out pitungan to the variable of birth variations of first-born

\begin{tabular}{lccc}
\hline & Fast (<13 months) & Average (14-23 months) & Long (>24 months) \\
\hline Pitungan divided by 9 & 40 & 13 & 6 \\
Pitungan divided by 4 & 34 & 27 & 6 \\
and 5 & 31 & 18 & 18 \\
Unknown & 105 & 58 & 30 \\
\hline Total & \multicolumn{2}{c}{ Source: Primary data }
\end{tabular}

\begin{tabular}{cccc}
\hline \multirow{2}{*}{ Pearson Chi-square } & Value & df & Asymp. Sig. (2 sides) \\
\cline { 2 - 4 } & 15.247 & 4 & 0.004 \\
\hline \multirow{3}{*}{ Source: Primary data } \\
\end{tabular}

\begin{tabular}{cccccc}
\hline \multirow{2}{*}{ Regression } & B & Std. Error & $\beta$ & T & Sig. \\
\cline { 2 - 5 } & 0.192 & 0.065 & 0.209 & 2.954 & 0.004 \\
\hline \multicolumn{5}{c}{ Source: Primary data }
\end{tabular}

Based on Table 5, the results of the Chi-square analysis explain that the relationship between the variable of carrying out/not carrying out pitungan and the variable of the birth variation of first-born shows a probability value $=0.004$. This result is less than the alpha of $5 \%$, which means that there is an effect of the variable of carrying out/not carrying out pitungan and the variable of the birth variation of first-born.

The results of the regression analysis show that $\mathrm{Y}=1.220+0.192 \mathrm{X}$, where the effect of both variables is 0.192 and the probability value $=0.004$ is smaller than the alpha of $5 \%$, which is significant (Table 5). The value of the positive regression coefficient concludes that the higher pitungan conducted, the faster the birth variation of the first-born.

Table 6.

Analysis results of Chi-square and Linear Regression about the variable of carrying out/not carrying out pitungan on the variable of the number of children of married couple

\begin{tabular}{lcc}
\hline & At least 2 & More than 2 \\
\hline Pitungan divided by 9 & 25 & 34 \\
Pitungan divided by 4 and 5 & 38 & 29 \\
Unknown & 47 & 20 \\
\hline Total & 110 & 83 \\
\hline \multicolumn{2}{c}{}
\end{tabular}

\begin{tabular}{cccccc}
\hline \multirow{2}{*}{ Pearson Chi-square } & Value & Df & Asymp. Sig. (2 sides) \\
\cline { 2 - 5 } & 9.879 & 2 & \multicolumn{2}{c}{0.007} \\
\hline \multirow{5}{*}{ Source: Primary data } \\
\hline \multirow{2}{*}{ Regression } & B & Std. Error & $\beta$ & T & Sig. \\
\cline { 2 - 5 } & -0.139 & 0.043 & -0.226 & -3.209 & 0.002 \\
\hline \multicolumn{5}{c}{ Source: Primary data }
\end{tabular}

Table 6 presents the results of the Chi-square analysis which shows the relationship between the variable of carrying out/not carrying out pitungan on the variable of the number of children of married couple that the probability value $=0.007$. This result is less than the alpha of $5 \%$, which means that there is an effect between both variables. 
The results of the linear regression analysis show that $\mathrm{Y}=1.713-0.139 \mathrm{X}$, where the effect of these variables is -0.139 and the probability value $=0.002$ is smaller than the alpha of $5 \%$ which means that it is significant. The regression coefficient is negative, so that the higher pitungan is conducted by the newlyweds, the higher tendency of having more than two children (Table 6).

Table 7.

Analysis results of Chi-square and Linear Regression about the variable of feeling safe on the variable of carrying out slametan

\begin{tabular}{lccc}
\hline \multicolumn{1}{c}{ Feeling safe } & Frequent & Occasional & Never \\
\hline Tentrem and safe & 39 & 39 & 0 \\
Healthy & 13 & 6 & 1 \\
Rahayu & 63 & 30 & 2 \\
\hline Total & 115 & 75 & 3 \\
\hline \multicolumn{4}{l}{ Source: Primary data }
\end{tabular}

\begin{tabular}{cccc}
\hline \multirow{2}{*}{ Pearson Chi-square } & Value & Df & Asymp. Sig. (2 sides) \\
\cline { 2 - 3 } & 9.140 & 4 & 0.058 \\
\hline \multirow{3}{*}{ Source: Primary data }
\end{tabular}

\begin{tabular}{cccccc}
\hline \multirow{2}{*}{ Regression } & B & Std. Error & $\beta$ & T & Sig. \\
\cline { 2 - 5 } & -0.229 & 0.129 & -0.127 & -1.773 & 0.078 \\
\hline \multicolumn{5}{c}{ Source: Primary data }
\end{tabular}

Table 7 shows the results of the Chi-square analysis which explains that the relationship between the variable of feeling safe and the variable of carrying out slametan with a probability value $=0.058$. This result is less than the alpha of $10 \%$, which means that there is an effect between the variables.

The result of regression analysis shows that $\mathrm{Y}=2.413-0.229 \mathrm{X}$, where the effect of carrying out slametan on feeling safe is -0.229 and the probability value $=0.078$ is smaller than the alpha of $10 \%$, which means it is significant (Table 7). The negative coefficient in the equation means that the more often slametan is carried out, the more healthy, peaceful, safe, and happy the people become.

Table 8.

Analysis results of Chi-square and Linear Regression about the variable of believe/disbelieve in primbon on the variable of feeling safe

\begin{tabular}{lccc}
\hline \multicolumn{1}{c}{ Primbon } & Tentrem and safe & Healthy & Rahayu \\
\hline Strongly believe & 59 & 15 & 74 \\
Believe & 17 & 2 & 18 \\
Disbelieve & 2 & 2 & 4 \\
\hline Total & 78 & 19 & 96 \\
\hline \multicolumn{4}{c}{ Source: Primary data }
\end{tabular}

\begin{tabular}{cccc}
\hline \multirow{2}{*}{ Pearson Chi-square } & Value & df & Asymp. Sig. (2 sides) \\
\cline { 2 - 4 } & 3.392 & 4 & 0.494 \\
\hline \multicolumn{4}{c}{ Source: Primary data }
\end{tabular}

\begin{tabular}{cccccc}
\hline \multirow{2}{*}{ Regression } & B & Std. Error & $\boldsymbol{\beta}$ & $\mathbf{T}$ & Sig. \\
\cline { 2 - 5 } & 0.001 & 0.129 & 0.001 & 0.008 & 0.994 \\
\hline \multicolumn{5}{c}{ Source: Primary data }
\end{tabular}

Table 8 shows the results of the Chi-square test analysis which explains that the variable of belief in primbon on the variable of the feeling safe with a probability value $=0.494$, in which the result is higher than the alpha of $5 \%$. It means that there is no effect between the variable of belief in primbon and the variable of feeling safe. 
The results of the regression analysis show that $\mathrm{Y}=2.092+0.001 \mathrm{X}$, where the effect of the variable of belief in primbon on the variable of feeling safe is 0.001 (positive) and the probability value $=0.994$ is higher than the alpha of $5 \%$, which shows no significance of the variable of belief in primbon on the variable of feeling safe (Table 8).

Table 9.

Analysis results of Chi-square and Linear Regression about the variable of carrying out/not carrying out pitungan on the variable of feeling safe

\begin{tabular}{cccc}
\hline & Tentrem and safe & Healthy & Rahayu \\
\hline Pitungan divided by 9 & 24 & 5 & 30 \\
Pitungan divided by 4 and 5 & 29 & 4 & 34 \\
Unknown & 25 & 10 & 32 \\
\hline Total & 78 & 19 & 96 \\
\hline
\end{tabular}

Source: Primary data

\begin{tabular}{cccc}
\hline \multirow{2}{*}{ Pearson Chi-square } & Value & Df & Asymp. Sig. (2 sides) \\
\cline { 2 - 3 } & 3.269 & 4 & 0.514 \\
\hline \multicolumn{3}{c}{ Source: Primary data }
\end{tabular}

\begin{tabular}{cccccc}
\hline \multirow{2}{*}{ Regression } & $\mathbf{B}$ & Std. Error & $\beta$ & $\mathbf{T}$ & Sig. \\
\cline { 2 - 5 } & 0.002 & 0.085 & 0.002 & 0.24 & 0.981 \\
\hline \multicolumn{5}{c}{ Source: Primary data }
\end{tabular}

Table 9 shows the results of the Chi-square analysis of the relationship between the variable of carrying out/not carrying out pitungan and the variable of feeling safe with the probability value $=0.514$. The result is higher than the alpha of $5 \%$, so that there is no effect between the variables.

The results of regression analysis show that $\mathrm{Y}=2.089+0.002 \mathrm{X}$, where the effect of carrying out $/$ not carrying out pitungan on feeling safe is +0.002 (positive) and the probability value $=0,981$ is higher than the alpha of 5\%, which means it is not significant (Table 9).

Table 10.

Analysis results of Chi-square and Linear Regression of the variable of feeling safe on the variable of birth variation of first-born

\begin{tabular}{lccc}
\hline \multicolumn{1}{c}{ Feeling safe } & Fast (<13 months) & Average (14-23 months) & Long (>24 months) \\
\hline Tentrem and safe & 44 & 23 & 11 \\
Healthy & 10 & 4 & 5 \\
Rahayu & 53 & 33 & 10 \\
\hline Total & 107 & 60 & 26 \\
\hline \multicolumn{2}{c}{ Source: Primary data }
\end{tabular}

\begin{tabular}{cccccc}
\hline \multirow{2}{*}{ Pearson Chi-square } & Value & df & \multicolumn{3}{c}{ Asymp. Sig. (2 sides) } \\
\cline { 2 - 6 } & 6.548 & 4 & 0.162 \\
\hline \multirow{5}{*}{ Source: Primary data } \\
\multirow{2}{*}{ Regression } & B & Std. Error & $\beta$ & T & Sig. \\
\cline { 2 - 6 } & -0.016 & 0.055 & -0.021 & -0.296 & 0.767 \\
\hline \multicolumn{5}{c}{ Source: Primary data }
\end{tabular}

Table 10 summarizes the results of the Chi-square analysis which explains the relationship between the variable of feeling safe on the variable of the birth variation of first-born with a probability value $=$ 0.162 , which results in higher than the alpha of $5 \%$. The result indicates no effect between the variables.

The results of the regression analysis show that $Y=1.635-0.016 \mathrm{X}$, where the effect of the variable of feeling safe on the variable of the birth variation of first-born is -0.016 and the probability value $=0.767$ is higher than the alpha of 5\% which means it is not significant (Table 10). 
Table 11

Analysis results of Chi-square and Linear Regression about the variable of feeling safe on the variable of the number of children

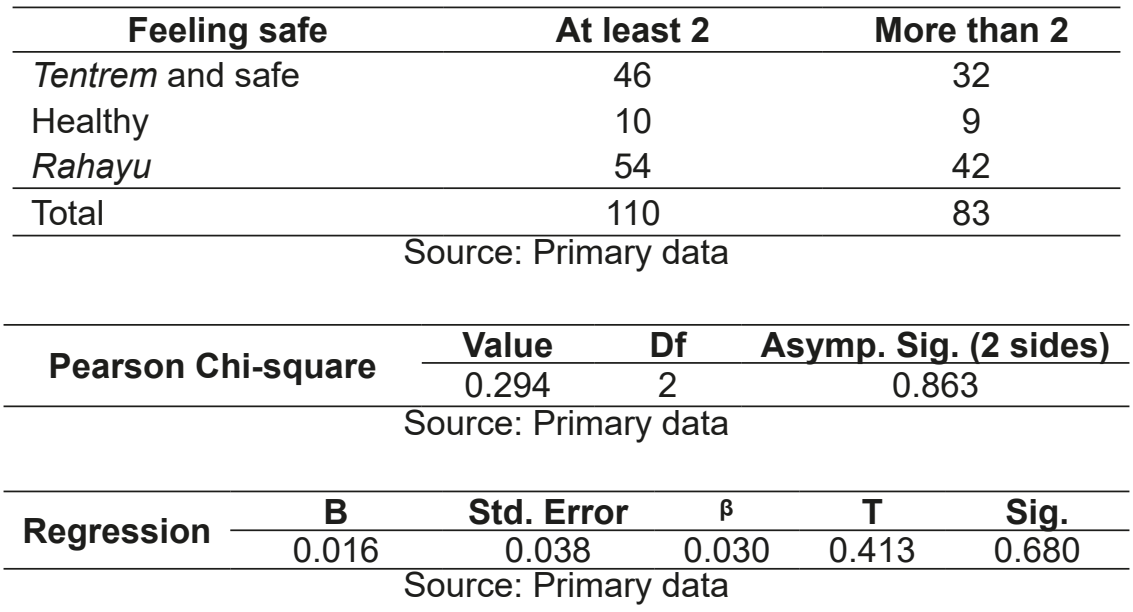

Table 11 shows the results of the Chi-square analysis in Table 9 between the variable of feeling safe and the variable of the number of children with a probability value $=0.863$. This result is higher than the alpha of $5 \%$, so that there is no effect between these variables.

The results of the regression analysis show that $\mathrm{Y}=1.397+0.016 \mathrm{X}$, in which feeling safe and the number of children is 0.016 and the probability value $=0.680$ is higher than the alpha of $5 \%$ which means it is not significant (Table 11).

\section{Believe in primbon and pitungan on the birth variations of first-born and the number of children in Javanese married couple}

The results of the study using the Chi-square and Linear Regression statistical tests prove an effect of the variable of primbon on the variable of pitungan, that the more the newlyweds believe in the primbon, the more the couple will carry out pitungan in determining the time of their marriage (Table 2). The belief in primbon is in the third layer of cultural form. It is as a socio-cultural system which exists in each individual of the Javanese ethnicity and is formed in a complex collective mind which is not a single idea but has been a series of various ideas as it is used as a code of conduct (Koentjaraningrat 2005). Certainly, nature does not create changes, but culture does. The reason is it has an important effect on adjustments that affects human biological appearance (Haviland 1999).

Belief in primbon is originally from an agrarian culture, in which issues concerning seed, birth, growth, life and death are experiential results (the result of life experience) which is cultural cosmic hence respect for ancestors (ancestor-culture) becomes important since they are considered as living intermediaries related to life and death. Agricultural culture is a process of human adaptation to the environment. The beginning of the agricultural cycle is carried out using the calculation system in the primbon book. Belief and behavior are always closely related even though they do not have to be regarded as a single unit (Malefitj 1989). The belief system is a culture but the behavior exists to reject or accept which is social behavior from learning outcomes, the results of long-standing awareness, internalization, and socialization from generation to generation members of the community.

Culture is a behavioral program of a population in organizing individuals, groups, and the environment into a high-quality system that adapts to its territory (Odum 1992). The Javanese had had a calculation of the time before the arrival of Buddhism, Hinduism, and Islam. Primbon and pitungan are native Javanese culture. Javanese people had had a time system, for example, a baby who is born will be attached to weton/neptu/pasaran, in which the names of the months and years of Javanese are from 
the original Javanese language. Neptu is the total value calculated by adding up the value of the day (Sunday, Monday, Tuesday, Wednesday, Thursday, Friday, Saturday, and Sunday) and its pasaran/ Javanese calendar (Pahing, Pon, Wage, Kliwon, and Legi). Every Javanese must know the weton/neptu/ pasaran because to make pitungan in determining the time of marriage is based on the calculation of the two weton/neptu/pasaran of the brides and grooms. The meaning of Pawukon or wuku=star = time is rahsa (having an external sense/roso jaba), internal sense/roso jero and sense of truth/roso sejati. Basically, humans have a basic innate nature from birth, so that in the development and journey of their life, they realize their life expectancy which is slamet in the world and the hereafter (Soedarsono et al. 1985).

The variable of belief in primbon has a significant effect on the variable of birth variations of first-born, and the variable of the number of children of married couple (Table $3 \& 4$ ). The regression test proved that there is a significant impact as the more married couples believe in the primbon, the faster they give birth to their first child. Marriage is carried out so that every adult is always looking for continuity to have children. The function and position of parents in Javanese society are representatives of life, have a high moral position, and are obliged to educate and care for their children until they are ready to take over the task of continuing their life (Mulder 1996).

The value of children for Javanese people is as a guarantee of old age, in which parents have a bond of emotional feelings with the child. Children are considered as a source of warmth and happiness in their family, therefore the subjects of married couples hardly have delayed pregnancy since their wedding, in which the statistical results proved significant. The more they believe in primbon, the more children are born by married couples (Table 4). In this case, children have economic value for the family workforce in communities whose livelihoods are farming, such as in the farming communities in Blitar Regency (Plosorejo, Sumberejo and Dawuhan) and Surabaya City (Gading), in which they generally have more than two children.

The parents or other people who are respected and understand pitungan will conduct pitungan to determine the time of marriage. The results of statistical tests proved that there is a significant effect on the variable of pitungan on the variable of birth variations of first-born, and the variable of the number of children of married couple. The Linear Regression test explains that the more couples conduct pitungan, the faster couples give birth to their first child and the more children they have (more than two children are born) (Table $5 \&$ 6). A study conducted by Hendrawati (2001) at the Surabaya Catholic Hospital also showed that there was a significant relationship between the mating season and birth variations because, at that period, Surabaya was inhabited by mostly Javanese. Pitungan underlies the bride and groom to determine the time of their marriage. The calculation of the time of marriage is obtained from the number of weton/neptu/pasaran of each couple whose number is added up and divided by the number 9 , number 5 , and number 4 . The final result is whether it is profitable for the pair of the prospective bride and groom or not. Dividing the number by 9,5 , and 4 depends on the belief who conduct pitungan. If there is a discrepancy, the calculation will be carried out again based on the front letter of the couple. However, in this study, none of them used pitungan based on the first letter of the bride and groom.

The formation of behavior or attitudes is very much influenced by our social thinking. Parental care provides an awareness of how we cannot avoid beliefs that have been transferred to the subconscious mind when we were children for about the first 10 years, without discriminating and limiting the analysis of our conscious thoughts. Since then, our conscious mind controls up to $95 \%$ of behavior, which is at the core of our life program (Lipton 2016). This shows the overall mechanism that the body is always affected by immaterial thoughts (something that is considered unimportant). Positive thinking is very important and feeling happy (well-being) is beneficial for health. Therefore, the more the couple believe in primbon and pitungan, the faster the first child is born and the more the number of children is born.

The variable of belief in primbon and pitungan on the variable of feeling safe is not proven well by the Chi-square and Linear Regression statistical tests (Table $8 \& 9$ ). Likewise, the variable of feeling safe on 
the variable of birth variations of first-born and the number of children of married couple is not proven to be good with the Chi-square and Linear Regression statistical tests (Table 10 \& 11).

The variable of feeling safe on the variable of carrying out slametan is proven by the Chi-square statistical test, where the probability value is smaller than the alpha of $5 \%$, which means that there is a significant relationship between the variable of feeling safe and carrying out slametan (Table 7). Linear Regression test shows that the more often people carry out slametan, the more it provides feeling safe. Javanese people who live in Blitar and Surabaya never neglect the slametan ritual. The meaning of slamet as a source of happiness cannot be separated from the ritual activities or ceremonies that are often carried out by Javanese people, whether those are considered small, simple, or formal ceremonies. Slametan is a communal party that symbolizes the mystical and social unity of their lives. Relatives, neighbors, and even ancestors who have died and the gods all sit together to vow to help each other to cooperate and there is social and occult recognition that gives blessing or justification for the activities that are carried out.

Slametan is always held in every activity of their life such as birth, marriage, death, relocation, planting, and harvesting, healing, and so on. The purpose of carrying out a slametan is that family and invited guests to get peace of mind and body or life which the Javanese call slamet.

The reason the Javanese people organize slametan is to protect themselves from the interference of spirits so that they feel no different from others by carrying out slametan. Their hearts feel safe and at peace with the environment around them because in slametan everyone is treated equally. The definition of the word slamet is gak-onok-opo-opo (nothing happens) and at peace with the surrounding conditions.

Slametan consists of four types (Geertz 2014); (1) life crisis of birth, circumcision, marriage, and death, (2) related to Islam holidays, (3) social integration such as cleaning the village, (4) slametan sela which is held depending on the events that are considered extraordinary such as relocation, changing names, being exposed to divination and so on. An event ordained by God is birth so that the slametan of birth and death are determined according to birth and death. Meanwhile, slametan for marriage, circumcision, or a place to live need to be determined by a calculation which is called pitungan.

\section{The theory implication and new research findings}

Research on pitungan and birth variations of first-born has never been studied in terms of how the process determines the time of marriage as it regulates the birth of the first child in Javanese communities. The results of this study are interesting because human behavior is not only influenced by social norms, cultural rules that generate a system that is tangible, perceived and shared by members of the supporting community, such as doing pitungan to influence biological processes and genetic factors. According to the theory of Evolutionary Psychology by David M. Buss, the choice of behavior, emotional reaction, and attitude to some extent is influenced by the human biological trait (Baron 2004). Inheritance factors (innate) cause variations to be passed on to the next generation, while selection refers to the fact that superior individuals will reproduce and survive, then select their partners to inherit the offspring to be born. The selection of a mate usually follows and has characteristics similar to our ancestors (Tassinary \& Hansen in Baron 2004).

Theory of Planned Behavior argues that by doing pitungan to determine the time of marriage, it leads the bride and groom to feel confident that their life will be happy. Belief in the calculation will be a desirable behavior and can overcome internal barriers. As with the Theory of Reasoned Action in the Theory of Planned Behavior, it includes a degree of irrationality and views social factors as normative beliefs. The explanation of pitungan is to select and plan when the wedding is considered "good" by the Javanese. The concept of a "good" day and month is an irrational factor, but the process of pitungan results will be rational if it directs at a specific goal, such as to create a slamet life without any disturbance, both physically and mentally, which results in the peace of mind of a couple. The more they believe in 
primbon, the more they conduct pitungan. Couples who carry out pitungan will give birth to children faster and have more than 2 children.

The choice of whether to carry out pitungan or not has gone through the choice of behavior that has been considered, the consequences and results have been evaluated and a decision has been made to carry out or not carry out pitungan which is reflected in the behavioral goal. It is peace of mind which is defined as life slamet mentally and physically. Pitungan is carried out by the parents of usually the bride and groom.

Pitungan is the behavior of calculating whether or not the match of the birthdays (weton/neptu/pasaran) of each prospective bride and groom. The suitability of this calculation is considered important for the prospective couple because it is considered as the basis for predicting a happy life, permanence, harmony, and family safety in the future. Pitungan is still carried out by a married couple as a form of obedience to their parents and ancestors (ancestral-cult). It is a form of the subjective norm that is believed by couple to gain peace of mind because the couples have made peace with their surroundings, including the unseen realm. The behavior of carrying out pitungan based on primbon is proven to have a significant effect on birth variations of first-born and the number of children of married couple due to the peace of mind manifested by feeling safe. The feeling brings the body and mind as a source of mixed energy and in a calm mind, there is a healthy body, so that the calculations are carried out. Married couples show a comprehensive mechanism of how the body (physical) is influenced by immaterial thoughts (something that is often considered unimportant) to become active energy or become a barrier to cell function to produce protein through the mechanism of repair or damage to the body. This study proves that the peace of mind of the couple will affect the speed, average, and delay of giving birth to the first child and the number of children born.

Research by Lipton (2016) explains that the power of the mind and cells move into the mind of the body and begin to work, so that positive thinking is very powerful in controlling our bodies and our lives. Positive thinking is very important and feeling happy (well-being) will transform our thoughts into positive energy, energizing life, and eliminating all bad prejudices. Positive thinking will have an impact on all life, especially on health.

\section{Conclusion}

Based on the results of the research and discussion above, it can be concluded that there is an impact of pitungan on the birth variations of first-born $(p=0.004)$, that the more the couple carry out the pitungan, the faster they give birth to their first child $(p=0.004)$ and the more children are born $(p=0.002)$. In this study, it is proven that there is an effect of belief in primbon on the birth variations of first-born $(p=$ $0.036)$ and the number of children born $(p=0.081)$, that the more the married couple believe in primbon, the faster the couple give birth to their first child $(p=0.020)$ and the more children are born $(p=0.041)$.

The slametan ceremony is also statistically proven to feeling safe $(p=0.058)$, meaning that the more often husband and wife practice slametan, the spouses feel slamet more increasingly $(p=0.058)$. Slametan ceremonies are still often carried out by the people of Blitar and Surabaya. Apart from being an expression of gratitude, slametan is done more to avoid the bad influences around them. By performing individual slametan, they feel safe and peaceful with their physical and magical environment.

The results of the statistical test of pitungan and belief in primbon on feeling safe explained that there is no effect of the couple who carried out the pitungan $(p=0.514)$ and belief in primbon $(p=0.494)$ with feeling safe. The reason why there is no effect on this measurement is the possibility that spouses do not carry out pitungan and do not believe in primbon. This study also does not carry out medical examinations such as hormonal examinations. However, additional measurement indicators are carried out, especially in the feeling safe concept. One of the reasons for the absence of feeling safe effect on the birth variation of first-born $(p=0.162)$ and the number of children of married couple $(p=0.863)$ 
is the belief in primbon and pitungan is increasingly changing, in which spouses think that primbon and pitungan are Javanese customary issues. Moreover, they do this because it is based on parental obedience.

Basically, the belief in primbon in the Javanese ethnic community sooner or later experiences a shift and change as a result of the growth and development of a culture that is called by the current generation a "super organic" culture which is the creation of the community itself and they become followers of the culture (McGee \& Warms 2013). They are mostly hardly controlled, but humanistic reactions will quickly react to these changes. The happiness of this ignorance will be experienced by individuals, while the culture known as social heritage is only a legacy that may remain limited to respecting the heritage of their ancestors.

The results of this study are expected to provide information to paramedics and hospitals about the birth season in certain months so that related parties, especially paramedics, hospitals, and health centers, particularly those in rural areas, can anticipate and prepare for the peak of birth needs, and provide input of knowledge to prospective couples of childbearing age to plan marriage physically and mentally. Therefore, prospective mothers can prepare for pregnancy and give birth to healthy children, especially in Javanese society in Indonesia.

\section{References}

Bailey RC, Jenike MR, Ellison PT, Bentley GR, Harrigan AM, \& Peacock NR (2008) The ecology of birth seasonality among agriculturalists in central Africa. Journal of Biosocial Science 24 (2):393-412. https://doi.org/10.1017/s0021932000019957.

Baron RA \& Byrne D (2004) Psikologi Sosial. Jakarta: Erlangga.

Bobak M \& Gjonca A (2001) The seasonality of life birth is strongly influenced by socio-demographic factors. Human reproduction 16 (7):1512-1517. https://doi.org/10.1093/humrep/16.7. 1512.

Condon RG \& Scaglion R (1982) The ecology of human birth seasonality. Human Ecology 10:495-510. https://doi.org/10.1007/BF01531169.

Danubio ME \& Amicone E (2001) Biodemographic study of a central Apennine area (Italy) in the 19th and 20th centuries: Marriage seasonality and reproductive isolation. Journal of Biosocial Science 33 (3):427-449. https://doi.org/10.1017/S0021932001004278.

DPMPTSP Kota Surabaya (2017) Demografi. [Accessed 23 July 2021]. http://dpm-ptsp.surabaya.go.id/ v3/pages/demografi.

Emlen JM (1984) Population Biology: The Coevolution of Population Dynamics and Behaviour. New York: Macmillan Publishing Company.

Endraswara S (2012) Memayu Hayuning Bawana. Yogyakarta: Narasi.

Geertz C (2014) Agama Jawa: Abangan, Santri, Priyayi dalam Kebudayaan Jawa. Jakarta: Komunitas Bambu.

Haviland WA (1999) Antropologi Jilid I. Jakarta: Erlangga.

Hendrawati LD (2001) Variasi musim kelahiran dan berat badan lahir. Thesis, Universitas Airlangga, Surabaya.

Henneberg M (1997) Seasonality of birth in a rural 19th century polish community. Journal of Human Evolution 6:715-717.

Holland B (1989) Seasonality of births: Stability and change in a developing country. Human Biology 61 (4):591-598.

Johnson JT, Ann TB, \& Palan VT (1975) Seasonality of birth for West Malaysia's two main racial groups. Human Biology 47 (3):295-307.

Koentjaraningrat (1994) Kebudayaan Jawa. Seri Etnografi Indonesia No. 2. Jakarta: Balai Pustaka.

Koentjaraningrat (2005) Pengantar Antropologi - Jilid 1. Jakarta: PT. Rineka Cipta.

Lipton BH (2016) The Biology of Belief. USA: Hay House.

Malefitj AW (1989) Religion and Culture: An Introduction to Anthropology of Religion. USA: Waveland Press, Inc. 
Mantra IB (2007) Demografi Umum. Edisi Kedua. Yogyakarta: Pustaka Pelajar.

McGee RJ \& Warms RL (2013) Theory in Social and Cultural Anthropology: An Encyclopedia. USA: Texas State University.

Meijer MJ (1971) Marriage Law and Policy in the Chinese People's Republic. Hong Kong: Hong Kong University Press.

Mulder N (1996) Pribadi dan Masyarakat di Jawa: Penjelajahan Mengenai Hubungannya Yogyakarta, 1970-1980. Jakarta: Pustaka Sinar Harapan.

Mulder N (2006) Mysticims in Java. Yogyakarta: Kanisius.

Odum HT (1992) Ekologi Sistem: Suatu Pengantar. Yogyakarta: Gadjah Mada University Press.

Purnamasari DM (2021) BKKBN: Angka kematian ibu dan bayi Indonesia masih tinggi. [Accessed 18 June 2021]. https://nasional.kompas.com/read/2021/02/04/11324381/bkkbn-angka-kematianibu-dan-bayi-indonesia-masih-tinggi.

Rajan SI \& James KS (2000) The interdepence of vital events: Twentieth-century Indian Kerala. Journal of Interdisciplinary History 31 (1):21-41. https://doi.org/10.1162/002219500551479.

Rosetta L \& Mascie-Taylor CGN (2007) Variability in Human Fertility. France: URA CNRS 1454, University Lyon I.

Siegel S (1997) Statistik Nonparametrik Untuk Ilmu-ilmu Sosial. Jakarta: Gramedia Pustaka Utama.

Soedarsono, Astuti R, \& Pantja SIW (1985) Aksara dan Ramalan Nasib dalam Kebudayaan Jawa. Yogyakarta: Proyek Penelitian dan Pengkajian Kebudayaan Nusantara (Javanologi) Direktorat Jenderal Kebudayaan Departemen Pendidikan dan Kebudayaan.

Subalidinata RS (1985) Aksara dan Ramalan Nasib dalam Kebudayaan Jawa: Primbon dalam Kehidupan Masyarakat Jawa. Yogyakarta: Proyek Penelitian dan Pengkajian Kebudayaan Nusantara (Javanologi) Direktorat Jenderal Kebudayaan Departemen Pendidikan dan Kebudayaan.

Sutarto A (2006) Sepuluh Pembagian Wilayah Jawa Timur. Jember: Unpublished. 